\title{
Liquefaction Mitigation Using Lateral Confinement Technique
}

\author{
W. R. Azzam and A. K. Nazir \\ Department of Structural Engineering, Tanta University, Tanta, Egypt \\ Correspondence should be addressed to A. K. Nazir, ashraf_nazir2003@yahoo.com
}

Received 22 July 2011; Revised 9 September 2011; Accepted 13 September 2011

Academic Editor: E. J. Sapountzakis

Copyright ( $) 2012$ W. R. Azzam and A. K. Nazir. This is an open access article distributed under the Creative Commons Attribution License, which permits unrestricted use, distribution, and reproduction in any medium, provided the original work is properly cited.

\begin{abstract}
The exploration of a series of shaking tests on circular model footing with and without cellular confinement constructed around the footing with variable depths and diameters under the effect of variable net bearing stress is studied. The effect of the confinement on the liquefaction time, final settlement, excess pore water pressure, and induced building acceleration were studied. The consequences showed that installing the cell with minimum diameter closer to footing and sufficient penetration depth significantly delayed the liquefaction time. It can be considered as an alternative technique to decrease both the lateral spreading and the final settlement below the foundation during the shaking. The results demonstrated that the cell reduced the excess pore water pressure within the confined zone and the pore water pressure migration outside the confined block where the liquefaction is induced. Moreover, the peak foundation acceleration of the confined footing soil system is reduced compared with the case of without cell confinement.
\end{abstract}

\section{Introduction}

Liquefaction takes place because of the pore water pressure accumulation in loose saturated sand deposits under earthquake loading, which causes a substantial reduction in the strength of the underlying soils. This phenomenon is usually accompanied by a large amount of ground surface subsidence. Occurrence of soil liquefaction beneath shallow foundations can also lead to excessive permanent deformations of buildings and other structures. If the soil strength reduces to an amount which is insufficient to support the weight of the structure, the bearing capacity failure will occur. Consequently, the structure will settle and rotate substantially due to loss of bearing capacity. Both types of behaviors, that is, foundation settlement and bearing capacity failure, have been observed during the past earthquakes. Structures or elements of infrastructure that are affected by earthquake loading can suffer severe damage while some of the damages are directly related to soil liquefaction [1-3]. In order to prevent or mitigate soil liquefaction, the factors that lead to liquefaction in the subsoil are important. These factors have been reported by different authors (e.g., Seed and Idriss [1]; Ishihara [4]; Mitchell [5]; Figueroa et al. [6]). The variety of most soil improvement techniques used for controlling liquefaction hazards is to evade large increases in pore water pressure during earthquake shaking. This can be achieved by densification of the soil and/or improvement of its drainage capacity. The soil improvement techniques as dynamic compaction, vibro stone columns, and wicks drainage were used worldwide to mitigate the liquefaction [7-9]. Moreover, improving liquefaction potential strength by using micropiles and inclined reinforcement is also investigated by McManus et al. [10]; Naein and Moayed [11]. These techniques of soil improvement against liquefaction aim to increase the soil density and develop the ideal densification. Based on this approach of densification, lateral confinement technique of soil underneath footing was adopted by many investigators without considering liquefaction phenomena but focusing only on improvement of the bearing capacity as stated by El Sawwaf and Nazer [12]. Exceptionally, for minor researchers investigated the effect of lateral containment by sheet pile placed below the embankment in liquefied soil as a method of liquefaction mitigation as confirmed by Kimura et al. [13] and Elgamal et al. [14]. Consequently, in the present paper, a new alternative technique is used for liquefaction mitigation by lateral confinement method compared with other technique of soil improvement to reduce liquefaction 


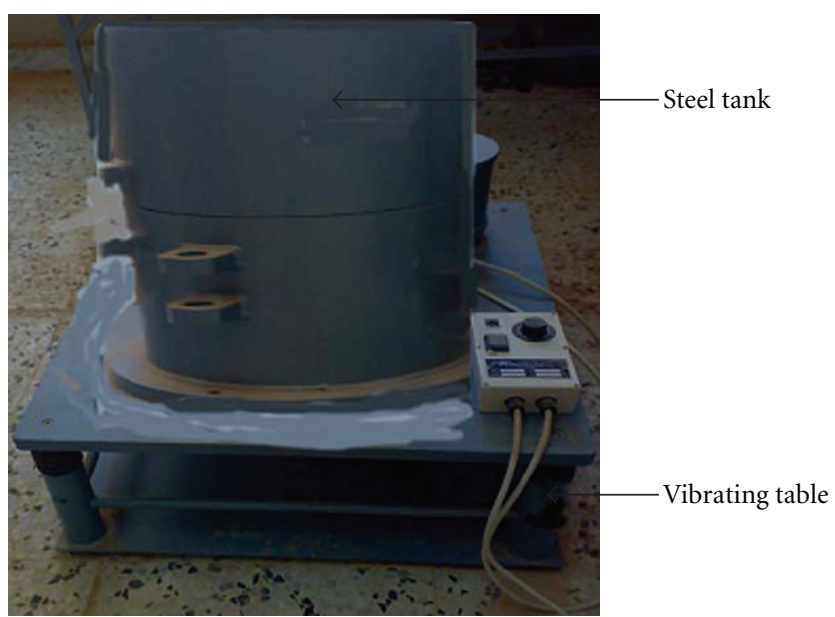

FIGURE 1: Test set up and soil tank rested on the vibrating table.

under the loaded footing soil system. This confinement was adapted using circular steel cell installed directly below the loaded footing in liquefied subgrade.

\section{Vibrating Table and Model Test Arrangement}

The physical tests described in this research were carried out on a shaking table with plans dimensions of $100 \mathrm{~cm} \times 100 \mathrm{~cm}$ and $45 \mathrm{~cm}$ height, Figure 1. Table vibration was performed under gravitational field of earth and it well controlled large amplitude, multi-axis input motions (A six degree of freedom). This table was designed to apply harmonic shaking. The shaking table was designed for vibrating range about $2 \mathrm{~Hz}$ with $0.35 \mathrm{~g}$ level of acceleration. This magnitude of shaking is necessary to liquefy the model ground under the footing when it is subjected to the vibration. The vertical amplitude displacement of this table was found to be $18 \mathrm{~mm}$.

The model tests were performed in a circular rigid steel tank which has inside diameter of $70 \mathrm{~cm}$ and $100 \mathrm{~cm}$ depth. The model tank was placed directly and fixed into the shaking table thought two pivots at the base of tank. The adopted model footing is circular rigid steel plate with diameter of $100 \mathrm{~mm}$ and thickness of $20 \mathrm{~mm}$. The tested footings have central threaded hole with diameter of $16 \mathrm{~mm}$. A circular steel cell with variable diameter and $1 \mathrm{~mm}$ thickness is designed as soil confinement under the footing model; this cell has a variable diameter and height.

\section{Test Material and Sample Preparation}

Fine-to-medium dry silica sand is used in this research. The shape of the grains is subrounded to rounded, while some are subangular. The specific gravity of the soil particles was found to be 2.59 . The maximum and minimum dry densities were found to be $17.34 \mathrm{kN} / \mathrm{m}^{3}$ and $15.1 \mathrm{kN} / \mathrm{m}^{3}$ and the corresponding minimum and maximum voids ratios are 0.354 and 0.645 , correspondingly. The particle size distribution was determined using dry sieving method. The effective size, uniformity coefficient, and coefficient of curvature for the tested sample were $0.145,3.7$, and $1.26 \mathrm{~mm}$, respectively. In order to set up the soil bed, the sand was poured in layers each of them $50 \mathrm{~mm}$ thickness by raining technique. The dry sand is allowed to rain through the air at a constant discharge rate and height of fall to achieve uniform densities. A series of tests were carried out to check the relative density obtained and uniformity of the sand samples by using three density cans placed at different location in the test tank. After pouring the sand, each mold was carefully excavated and the density of the sample is back calculated. The raining technique used in this study provided a uniform relative density of approximately $72 \%$ with a unit weight of $16.65 \mathrm{kN} / \mathrm{m}^{3}$. After the sand bed was constructed at dry condition with the previously mentioned density, the tap water was poured into the tank to immerse the sand to get the saturated condition. The saturated density of the tested sand was also obtained using these cans placed at different locations and the resulting saturated density was found to be $19.12 \mathrm{kN} / \mathrm{m}^{3}$ for all test series.

\section{Experimental Program}

After the sand bed was set up, the cells were pushed vertically into the sand at the design place and predetermined depth and diameter, the footing was placed directly at the top of the confined soil. A series of shaking tests were carried out for the footing with and without confinement cell under saturated condition. The footing and the confined sand bed was subjected to shaking until the system failed due to liquefaction. The time required to reach the liquefaction and the final settlement of the footing at failure was recorded for each test. Where the shaker was switched on, hence, the confined footing soil system was subjected to an input sinusoidal base motion with frequency of $2 \mathrm{~Hz}$. The acceleration of the table was recorded using an accelerometer fixed at the base of table. Amplitude of $0.35 \mathrm{~g}$ was recorded.

The experimental program was designed to investigate the effect of lateral confinement on the liquefaction mitigation. The geometry of the soil, model footing and confining cell is shown in Figure 2, the cell diameter and its depth in addition to applied net bearing stress $(\sigma)$ were varied to evaluate their effects on the liquefaction time $\left(t_{\text {Liq }}\right)$ and the final settlement of the model footing $\left(S_{f}\right)$. The results were recorded after liquefaction occurrence. These results are shown in Table 1 which gives the details of studied parameters and conditions. The shaking tests were performed at different cell geometry $(D / B, h / B)$ and net bearing stress $(\sigma=15,30$, and $60 \mathrm{kPa})$ in order to determine the liquefaction time and final settlement.

The net bearing stress is applied using dead weights made of circular plates of lead. These circular weights have a diameter of $130 \mathrm{~mm}$ and $20 \mathrm{~mm}$ thickness, also the plate has a central hole of $18 \mathrm{~mm}$. A central threaded rod is attached to the center of the footing and two steel nuts have $18 \mathrm{~mm}$ thickness are tied in the rod flushed to the top surface of the footing to prevent the lead weights to be touched with soil or footing surface during shaking. The final settlement of the footing-cell system was recorded, and the induced maximum pore water pressure for each case at the depth 
TABLE 1: Model tests program.

\begin{tabular}{lcr}
\hline Series & Constant parameters & Variable parameters \\
\hline 1 & $D / B=h / B=0.0$ without confinement (control values) & $\sigma=15,30$ and $60 \mathrm{kPa}$ \\
2 & $h / B=0.50$ and $\sigma=15 \mathrm{kPa}$ & $D / B=1,1.25,1.5$ and 1.75 \\
3 & $h / B=0.50$ and $\sigma=30 \mathrm{kPa}$ & $D / B=1,1.25,1.5$ and 1.75 \\
4 & $h / B=0.50$ and $\sigma=60 \mathrm{kPa}$ & $D / B=1,1.25,1.5$ and 1.75 \\
5 & $h / B=1.00$ and $\sigma=15 \mathrm{kPa}$ & $D / B=1,1.25,1.5$ and 1.75 \\
6 & $h / B=1.00$ and $\sigma=30 \mathrm{kPa}$ & $D / B=1,1.25,1.5$ and 1.75 \\
7 & $h / B=1.00$ and $\sigma=60 \mathrm{kPa}$ & $D / B=1,1.25,1.5$ and 1.75 \\
2 & $h / B=1.50$ and $\sigma=15 \mathrm{kPa}$ & $D / B=1,1.25,1.5$ and 1.75 \\
3 & $h / B=1.50$ and $\sigma=30 \mathrm{kPa}$ & $D / B=1,1.25,1.5$ and 1.75 \\
4 & $h / B=1.50$ and $\sigma=60 \mathrm{kPa}$ & $D / B=1,1.25,1.5$ and 1.75 \\
5 & $h / B=2.00$ and $\sigma=15 \mathrm{kPa}$ & $D / B=1,1.25,1.5$ and 1.75 \\
6 & $h / B=2.00$ and $\sigma=30 \mathrm{kPa}$ & $D / B=1,1.25,1.5$ and 1.75 \\
7 & $h / B=2.00$ and $\sigma=60 \mathrm{kPa}$ & $D / B=1,1.25,1.5$ and 1.75 \\
\hline
\end{tabular}

See Figure 2 for definition of the variable.

$\mathrm{B}$ is constant $=100 \mathrm{~mm}$, and $\sigma$ is the net bearing stress in $\mathrm{kPa}$.

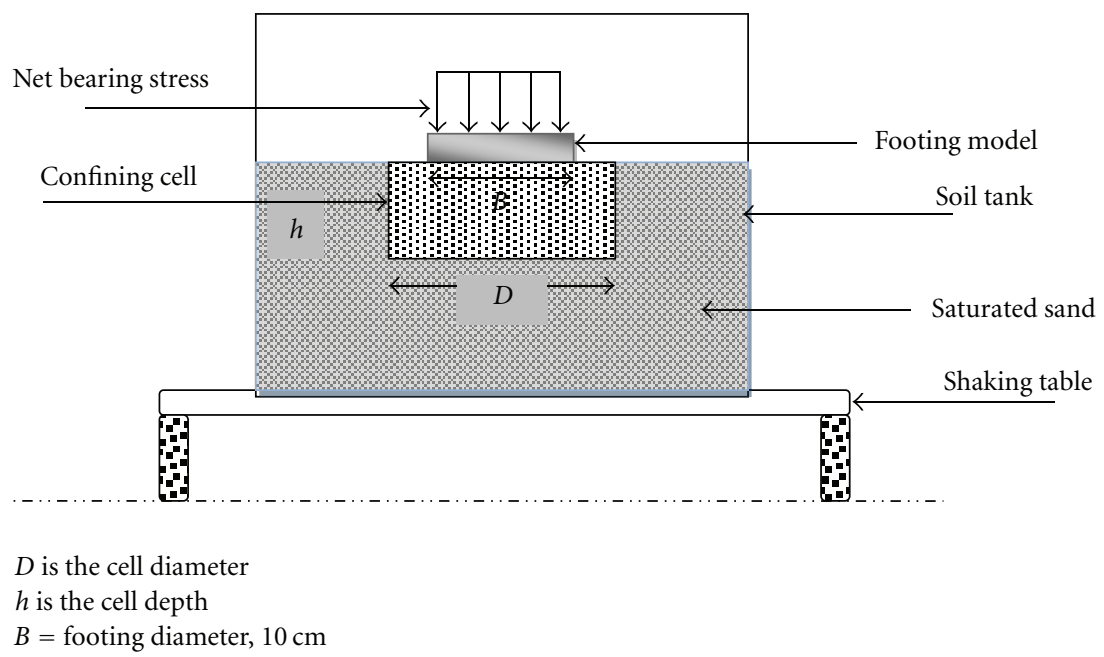

Figure 2: Geometric parameters of confined sand foundation model on shaking table.

equal to $0.25 \mathrm{~B}$ below the foundation (within the confined zone) was also measured by pore water pressure transducers. These transducers are generally strain gauge type, precisely catch minute fluctuation in pressure with high accuracy. The transducers are mainly used as instruments to measure distributions of pore water pressure in the model ground and to observe the consolidation process during the flight. In case of liquefaction tests, these transducers are essential to locate the liquefied portion and its magnitude. The maximum peak foundation acceleration was also recorded.

\section{Results and Analysis}

5.1. Effect of Cell Geometry on the Liquefaction Time. In order to study the effect of lateral confinement below the foundation using the adopted steel cell on the liquefaction time, Figure 3 is constructed. The figure shows the variation of the cell geometry $(D / B)$ with obtained liquefaction time, the time required until the soil to be liquefied, at different embedment cell ratios. From this figure, it is observed that as the cell diameter decreases and installed close to the footing with sufficient embedded depth, the time for induced liquefaction is increased. Also, it is observed that the installation of the cell produces significant lateral confinement. This confinement has an effective role to prevent the lateral spreading associated with liquefaction below the foundation. It is also concluded that the cell has delayed the liquefaction occurrence. The liquefaction time for the footing is increased due containment effect, this increase is directly related to both of cell diameter and its embedment ratio, in addition to acting net bearing foundation stress as illustrated in Figures 3(a), 3(b), and $3(\mathrm{c})$. As the ratio $(D / B)$ is decreased, the liquefaction time has belated the cell which installed with adequate depth 


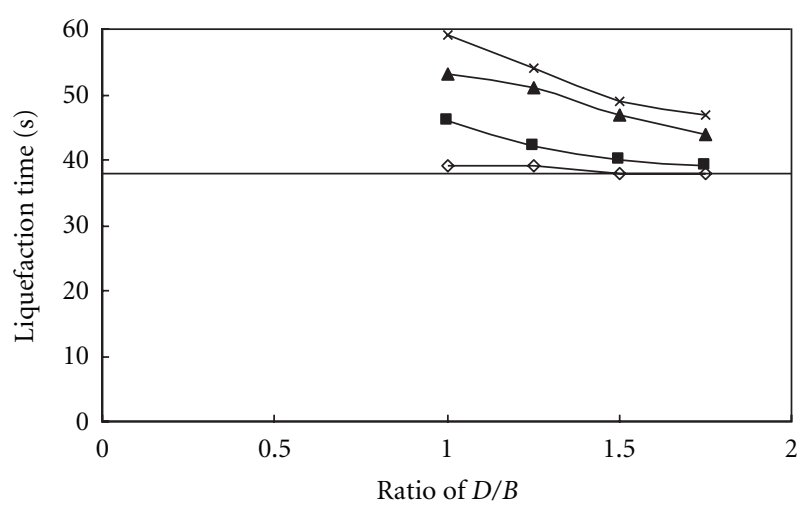

(a) $\sigma=15 \mathrm{kPa}$

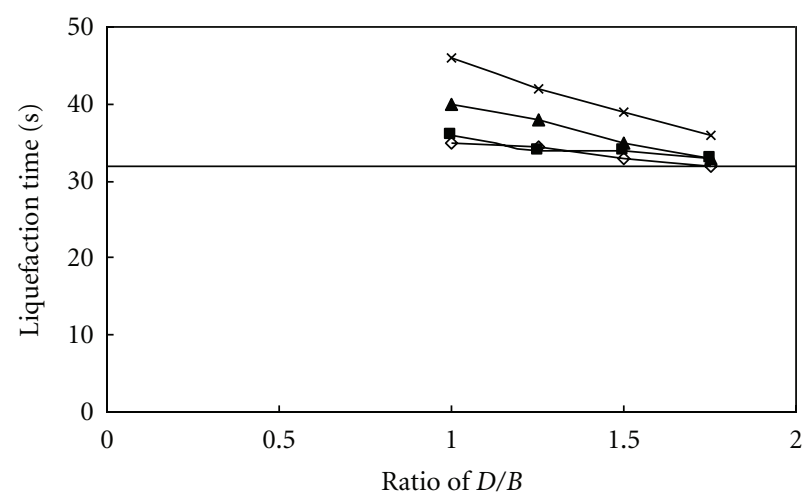

(b) $\sigma=30 \mathrm{kPa}$

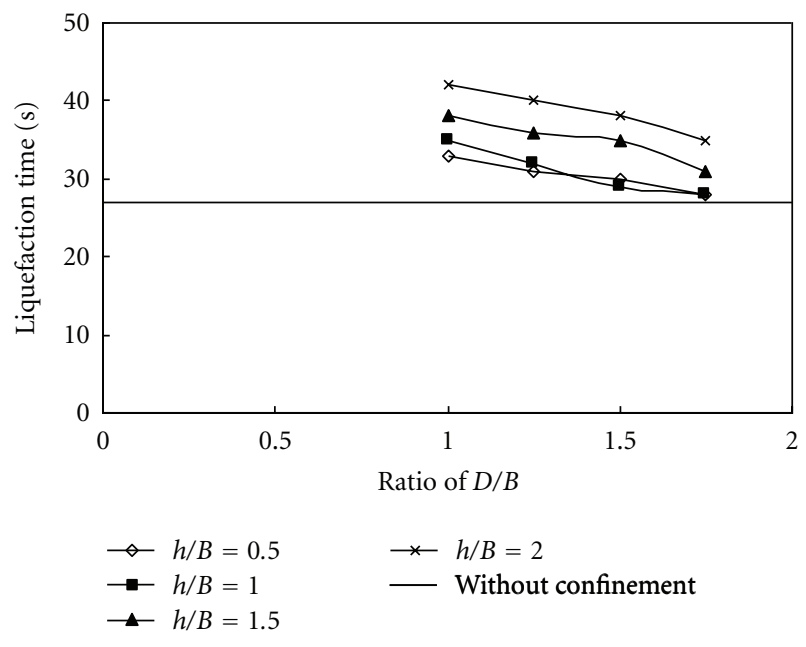

(c) $\sigma=60 \mathrm{kPa}$

FIgURE 3: Variation of the liquefaction time with cell geometry at different stress.

$(h / B$ at least 1.5$)$ is provided a considerable improved zone. Increasing the cell depth acts as vertical reinforcement providing additional shear resistance of the liquefiable soil during the shaking.

This was confirmed by Naein and Moayed [11] which reported that the liquefaction potential strength is increased by using micropiles. When the cell diameter is decreased, both the foundation and the confined subgrade behave as a coherent compacted mass, while increasing the cell diameter decreases the degree of improvement and the produced densification; moreover, the lateral spreading is increased as a result that the liquefaction is rapidly induced.

The improved soil mass created by installing the such cell acts as a resistant coherent body which improves the compaction properties of liquefied layer and also provides suitable load bearing capacity to transfer structural loads to the ground.

The time for liquefaction at failure is depended on the net bearing stress at the low stress level, Figure 3(a) $\left(\sigma=15 \mathrm{kN} / \mathrm{m}^{2}\right)$, the time obtained for liquefaction is more than the time at the higher stress level as shown in Figures 3(b) and 3(c). At low net bearing stress $(\sigma=$ $\left.15 \mathrm{kN} / \mathrm{m}^{2}\right),(D / B=1$ and $h / B=2)$ the liquefaction time is increased by $56 \%$ of its initial value and reached $55 \%$ at high stress level $\left(\sigma=60 \mathrm{kN} / \mathrm{m}^{2}\right)$. This increase in liquefaction time is again justified that the presence of such cell causing a progressive densification to the confined subgrade and acted as an improved zone compared with other techniques of improvement. This approach is valuable to delay the liquefaction from occurrence as stated by Kokusho [15, 16] who validated the concept of delayed liquefaction and confirmed the present study.

5.2. Effect of Applied Net Bearing Stress on the Induced Liquefaction Time. Figure 4 shows the variation of the liquefaction time with acting stress at different cell geometry. It noticed that increasing the net bearing stress leads to decrease in the liquefaction time at different cell diameter and depth. The presence of the structure stress has a clear influence on the behavior of the soil supporting it. The acting stress can produce dilative behavior in the soil underneath, resulting not only in a significant increase in soil strength and stiffness, but also in increasing the potential for pore pressure migration and the liquefaction is induced swiftly at high stress level. Regarding Figures 4(a), 4(b), and 4(c), it is found that increasing the net bearing stress distinctly reduced liquefaction time.

This reduction depended on the region of confined zone or ratio $(D / B)$ and $(h / B)$. Once the cell depth is increased, the time is increased, but increasing the cell diameter causes a progressive decrease in the liquefaction time. On the other hand, when the cell diameter is increased the chance to mitigate lateral spreading of supporting soil is decreased, hence the liquefaction time took place quickly.

5.3. Effect of Cell Geometry on the Final Footing Settlement. Since the confined zone was able to limit lateral migration of foundation soil toward the free field, the observed surface footing settlement at different cell geometry and under different net bearing stresses was illustrated in Figure 5. The measured final settlement after liquefaction of the confined footing soil system was decreased in reference with the footing without containment. For the confining cell which installed closely the footing $(D / B=1.00)$, the percentage of settlement reduction is $11 \%$ regarding to the original value for shallow cell $(h / B=0.5)$, the percentage 


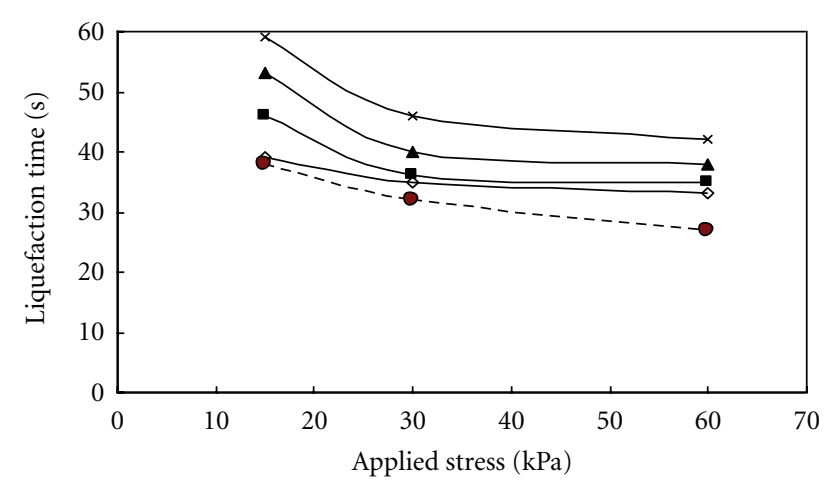

(a)

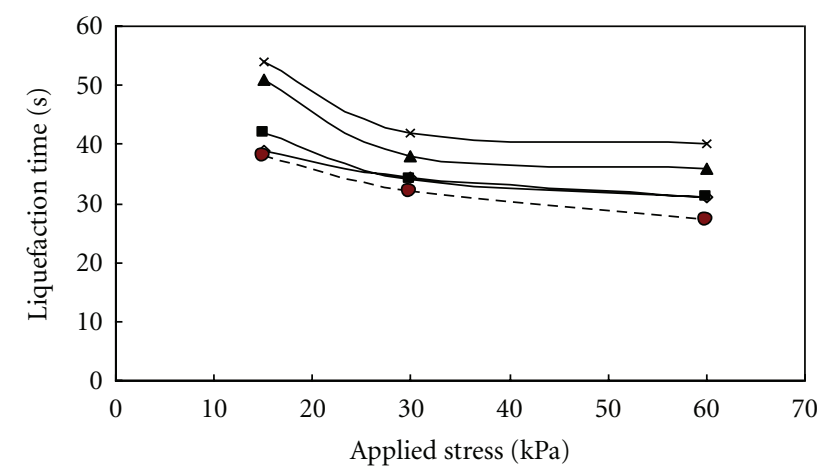

(b)

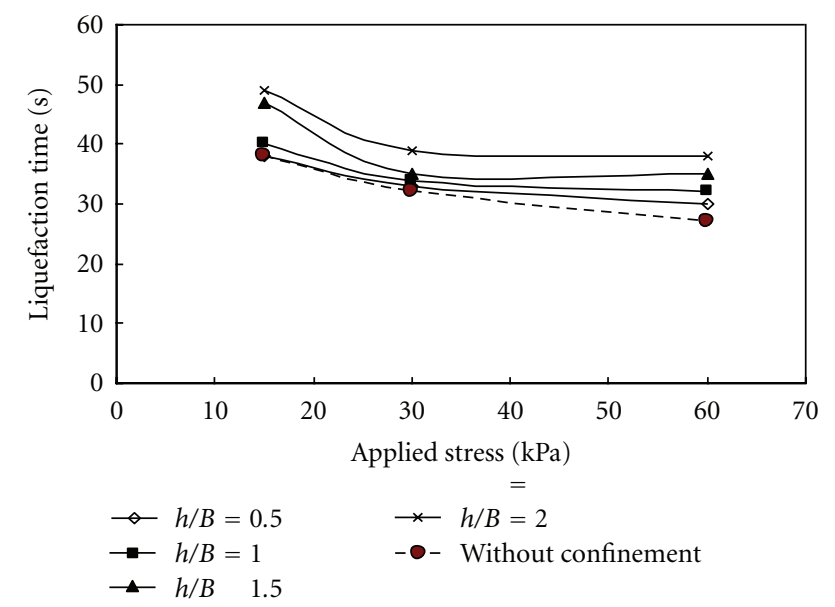

(c)

FIGURE 4: Variation of the liquefaction time with net bearing stress at different cell dimension.

reached $44.5 \%$ for deep cell $(h / B=2.00)$. These values are for low bearing stress, $15 \mathrm{kPa}$. While for higher bearing stress, $60 \mathrm{kPa}$, these values reached $18.5 \%$ and $50 \%$, respectively. The cell and the confined block below the foundation behave as a densified sand column which can be considered a remediation technique by densefaction. The cell provided overall foundation strength and increased the subgrade stiffness; therefore, the final settlement of confined footing soil system is decreased during the shaking, Figure 5. The reduction in the settlement is related to the cell diameter and its embedement depth wherever, as

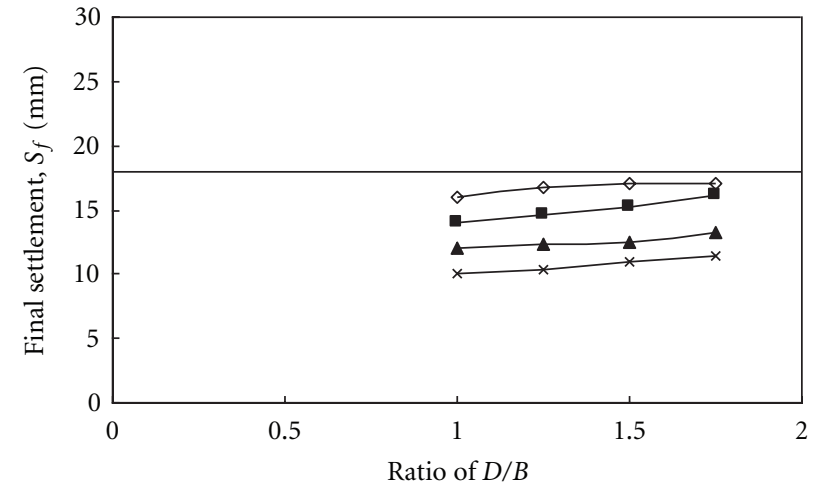

(a)

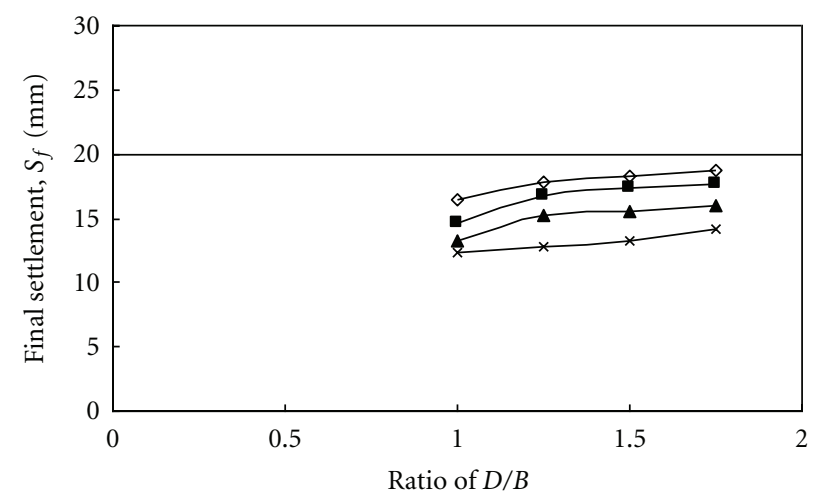

(b)

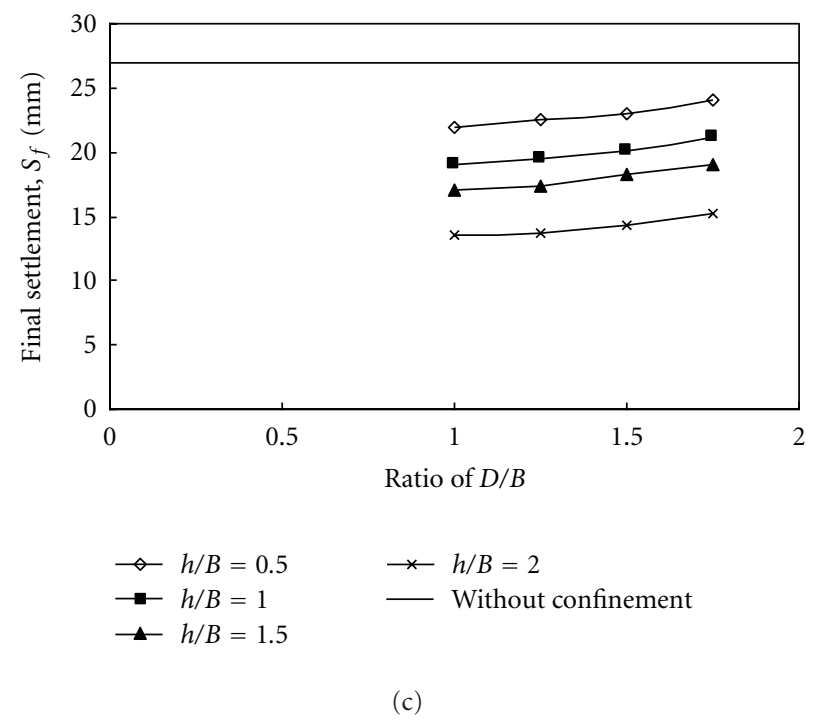

FIGURE 5: Variation of the final footing settlement with cell geometry at different stress.

the cell diameter is decreased and installed to sufficient depth, the footing settlement is decreased. At $D / B=1$ and $h / B \geq 1.5$, the cell acted as a constraint which prevented the enclosed foundation soil from flowing into the free field accordingly, the settlement associated with liquefaction is decreased.

However, increasing footing stress has provided a distinct increase in net settlement after liquefaction as presented in 
Figures 5(a), 5(b), and 5(c). It is noticed that at low acting stress, Figure 5(a), the settlement values sharply decreased compared with other cases at which the confining stress is increased as shown in Figures 5(b) and 5(c). Linear relationships were deduced for settlement versus cell geometry, these linearities were backed to the densification effect caused by confined cells. It can be also concluded that for the same $D / B$ ratio, the deeper the cell, the smaller settlement, this trend is observed at different acting stress. However, the relationship between the cell geometry and settlement is significantly affected by the acting foundation stresses. At the same cell geometry, the higher footing stress, the higher the settlement.

\subsection{Effect of Cell Geometry on the Induced Excess Pore Water} Pressure. It is well known that as the water pressure increases during ground shaking as a result of an earthquake, the ground water may find its way to the ground surface to relief the excess pore pressure. However, installing the confining cell with predetermined depth can significantly influence the pore pressure migration. It can be seen that the cell modifies and decreases the induced excess pore water pressure as shown in Figure 6, which presents the relationships between cell geometry and the measured excess pore pressure at depth $0.25 B$ within the confined zone below the foundation. It is noticed that the cell has provided an effective containment below the footing and produced subgrade densification, thus the excess pore water pressure was significantly reduced and it was not developed in the confined region.

At the same cell diameter, the excess pore pressure is decreased with increasing the cell depth compared with cases without cell as distinctly shown in Figure 6. It is also noticed that, at small cell diameter with sufficient embedement depth, the migration of the pore water pressure has totally gone below the confined zone. The excess pore water pressure is developed under the confined zone. As a result, the liquefaction is induced outside the confined block. It can be justified that the footing and the confined subgrade acted as a deep foundation hence the liquefaction is developed at the base of cell, where the pore pressure migration is considered. Pore water pressure migration occurs during and after an earthquake, when pore water pressures will be higher in a liquefiable zone than in an adjacent confined/improved zone due to the larger shear deformations that occur in the liquefiable soil. The difference in pressures between the two zones induces flow into the confined zone, but the cell prevents the flow through confined block, therefore, all the migration has taken their way parallel to cell depth and below the confined cell. This can cause an increase in pore water pressure and a potential decrease in strength at the bottom of the improved area. Consequently, liquefaction is obtained at the bottom of the cell due to additional increase in excess pore pressure. This can distinctly noted with higher acting stress $\left(\sigma=30\right.$ and $\left.60 \mathrm{kN} / \mathrm{m}^{2}\right)$ as shown in Figures $6(\mathrm{~b})$ and $6(\mathrm{c})$. Where increasing the foundation stress leads to an increase in resulting excess pore pressure and reducing stability of the subgrade, the acting stress has increased the buildup excess pore water pressure and made the way to develop the liquefaction below the confined block.

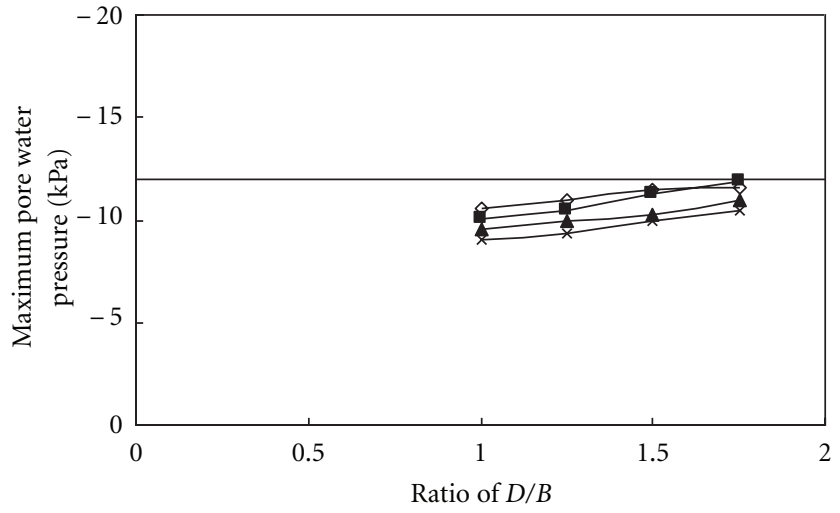

(a)

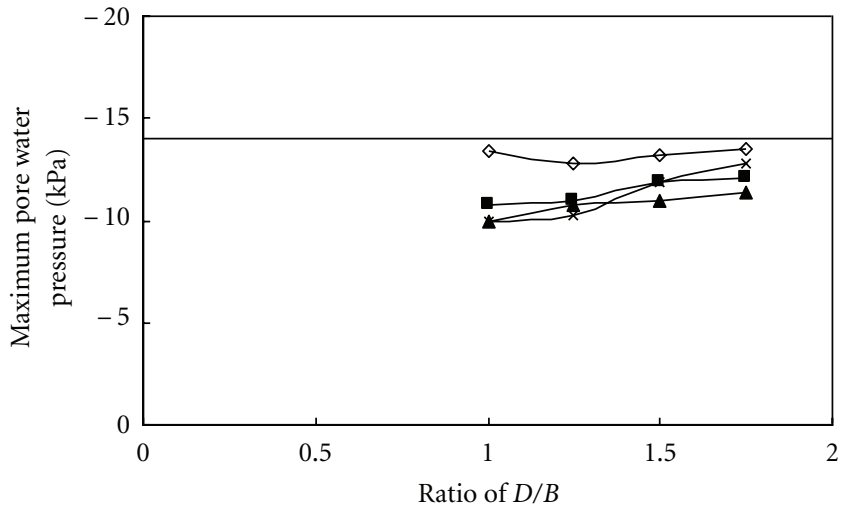

(b)

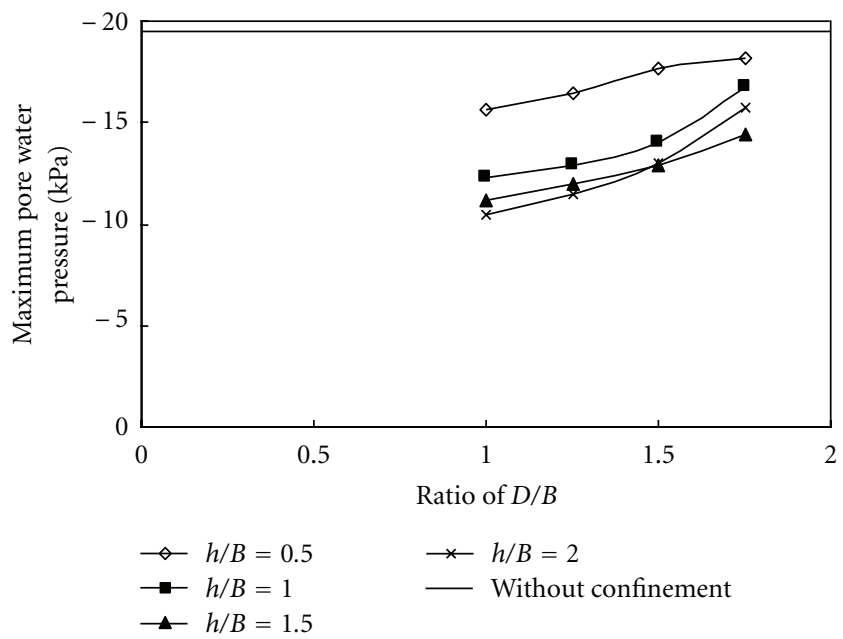

(c)

Figure 6: The relation between induced maximum pore water pressure and cell geometry at different stress.

5.5. Effect of Cell Geometry on the Peak Foundation Acceleration. In order to investigate the effect of installing the cell below the foundation in liquefied soil on the peak foundation acceleration, the relationship between the measured peak footing acceleration with cell geometry is shown in Figure 7 at different net bearing stress. It has been found that the cell can alter and decrease the resulting footing 


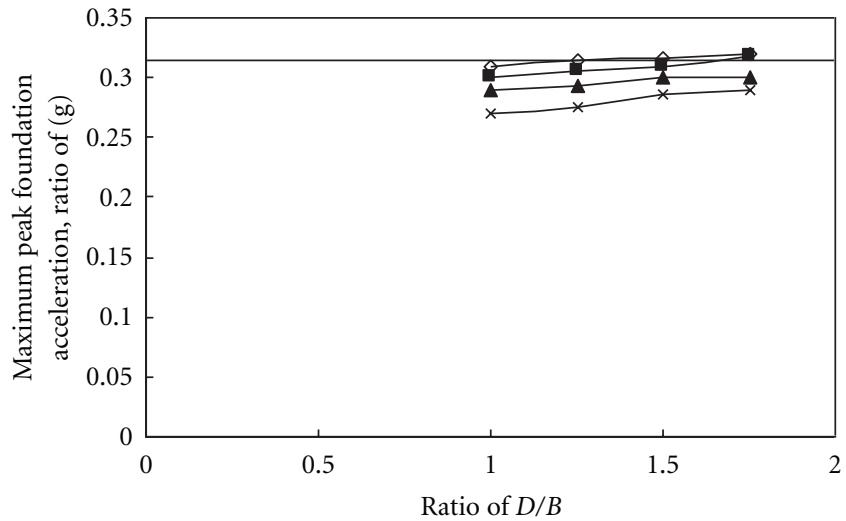

(a)

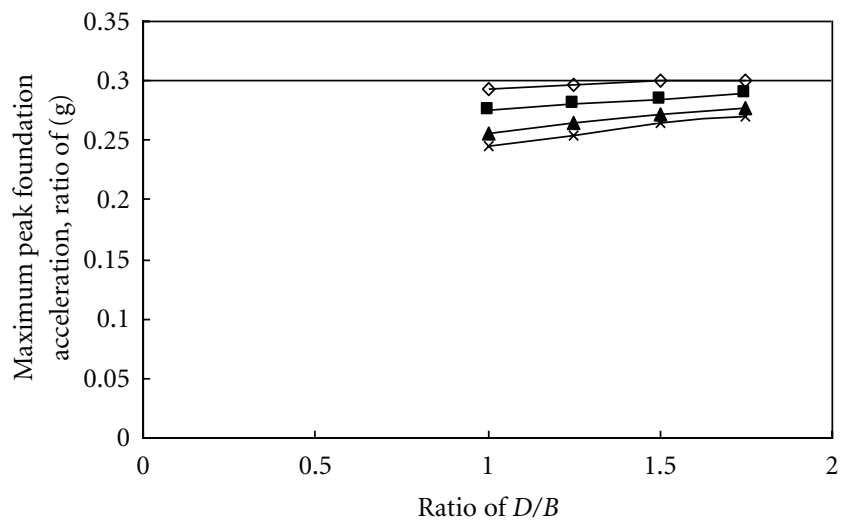

(b)

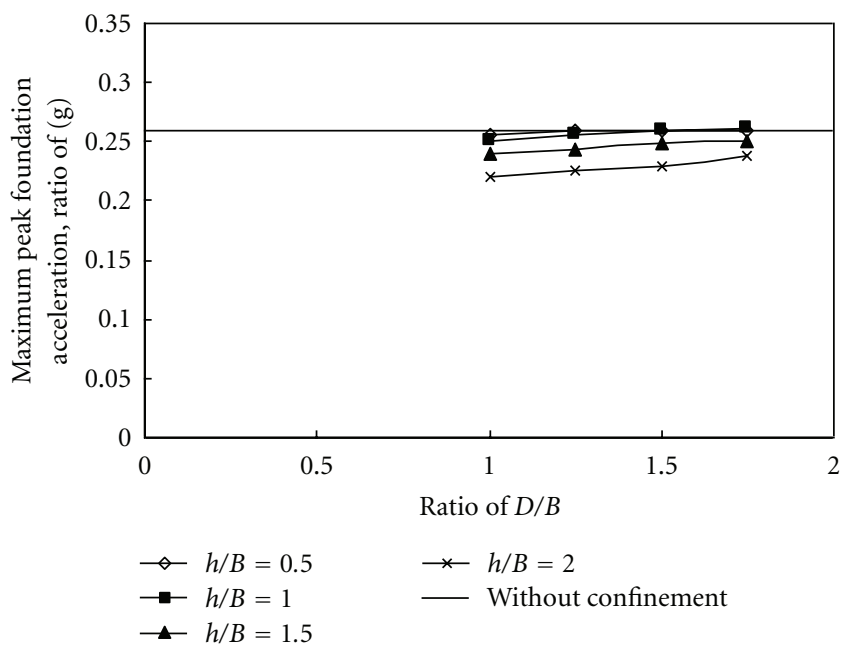

(c)

FIGURE 7: The relation between induced maximum peak foundation acceleration and cell geometry at different stress.

acceleration compared with other cases of normal footing without cell. As cell diameter is decreased, the obtained peak acceleration is decreased. The reduction in the footing peak acceleration is also affected by the cell depth where the peak foundation acceleration is sharply decreased with the increase of the cell depth. At lower cell diameter with sufficient anchorage depth, soil particles moved into tighter configuration increasing density, and a progressive densification is occurred, then the subgrade stiffness is appreciably increased. The foundation and the confined block within the liquefiable soil behave as if stiff one unit that resists and absorbs the ground acceleration. As a result, a distinct reduction in the peak footing acceleration is observed. On the other way, the peak footing acceleration is also affected by exerted confining stress, increasing the confining stress leads to significant decrease in footing acceleration as shown in Figures $7(\mathrm{a}), 7(\mathrm{~b})$, and $7(\mathrm{c})$. At the same cell depth as the confining stress gradually increased, the peak footing acceleration is decreased. It can be justified that installing the cell below the foundation not only increases the subgrade stiffness but also improves the foundation stability during the earthquake shaking as confirmed in Figure 7 which clearly shows that the peak footing acceleration is considerably decreased due to confinement effect obtained by such cell, although the improved zone is increased. It can be concluded that this technique of liquefaction mitigation by lateral confinement is more effective than of other techniques of soil densification because this confinement technique is decreases the foundation peak acceleration and improves the subgrade behavior.

\section{Conclusion}

The major conclusions from the experiments are as follows.

(1) Installing the confining cell below the foundation provided overall foundation strengthening and increased the subgrade stiffness during the earthquake shaking. It also considered a good method to control the lateral spreading of foundation soil associated with liquefaction.

(2) The cell and the confined block below the foundation acted as a densified sand column or coherent mass which can be considered a remediation technique by densefaction.

(3) Using such cell has delayed and increased the liquefaction time for the confined footing soil system due to its produced progressive densification.

(4) As the cell diameter decreased and installed with sufficient embedment depth, the liquefaction potential is substantially improved. Also, the time for induced liquefaction is increased.

(5) Increasing the net bearing stress leads to decreasing the time to induce liquefaction and produce dilative behavior in the soil underneath.

(6) The cell is able to limit lateral migration of foundation soil and significantly decrease the final settlement after liquefaction.

(7) The confining cell has a great influence in altering the pore pressure migration and reducing the induced excess pore pressure within the confined region. The excess pore pressure was developed below 
the confined zone, and the liquefaction was induced outside the confined block.

(8) The peak foundation acceleration of the confined footing soil system is reduced when the cell is installed with minimum diameter and sufficient depth.

\section{References}

[1] H. B. Seed and I. M. Idriss, "Simplified procedure for evaluating soil liquefaction potential," ASCE Journal of the Soil Mechanics and Foundation Division, vol. 97, no. 9, pp. 12491272, 1971.

[2] S. Yasuda, Liquefaction: Investigation and Countermeasures, Kajima Syuppankai, 1997.

[3] D. B. Chu, J. P. Stewart, S. Lee et al., "Documentation of soil conditions at liquefaction and non-liquefaction sites from 1999 Chi-Chi (Taiwan) earthquake," Soil Dynamics and Earthquake Engineering, vol. 24, no. 9-10, pp. 647-657, 2004.

[4] K. Ishihara, "Liquefaction and flow failure during earthquakes (Rankine lecture)," Geotechnique, vol. 43, no. 3, pp. 351-415, 1993.

[5] J. K. Mitchell, Fundamentals of Soil Behavior, John Wiley \& Sons, New York, NY, USA, 1993.

[6] J. L. Figueroa, A. S. Saada, and M. Dahisaria, "Evaluation of soil liquefaction by energy principles," ASCE Journal of Geotechnical Engineering, vol. 120, no. 9, pp. 1554-1569, 1994.

[7] K. Dise, M. Steven, and J. L. Von, "Dynamic liquefaction to mitigate liquefiable embankment foundation soils," ASCE Journal of Geotechnical and Geoenvironmental Engineering, no. 45, pp. 1-5, 1994.

[8] R. Luehring, L. Snoteland, and M. Stevens, "Liquefaction mitigation of a silty dam foundation using vibro-stone columns," in Proceedings of the 21st USSD Annual Meeting and Lecture, Denver, Colo, USA, 2001.

[9] T. Shenthan, R. Nashed, S. Thevanayagam, and G. R. Martin, "Liquefaction mitigation in silty soils using composite stone columns and dynamic compaction," Journal of the Earthquake Engineering and Engineering Vibration, vol. 3, no. 1, pp. 39-50, 2004.

[10] K. McManus, J. Turner, and G. Chartom, "Inclined reinforcement to prevent soil liquefaction," in Proceedings of the Annual NZSEE Technical Conference, pp. 523-533, New Zealand, 2005.

[11] S. Naein and R. Z. Moayed, "Improving liquefaction potential strength by using Micropiles," IAEG 509, the Geological Society of London, London, UK, 2006.

[12] M. E. El Sawwaf and A. Nazer, "Behavior of circular footings resting on confined granular soil," Journal of Geotechnical and Geoenvironmental Engineering, vol. 131, no. 3, pp. 359-366, 2005.

[13] T. Kimura, J. Takemura, A. Hiro-oka, M. Okamura, and T. Matsuda, "Countermeasures against liquefaction of sand deposits with structures," in Proceedings of the 1st International Conference on Earthquake Geotechnical Engineering, K. Ishihara, Ed., vol. 3, pp. 1203-1224, A.A. Balkema, Rotterdam, The Netherlands, 1997.

[14] A. Elgamal, E. Parra, Z. Yang, and K. Adalier, "Numerical analysis of embankment foundation liquefaction countermeasures," Journal of Earthquake Engineering, vol. 6, no. 4, pp. 447-471, 2002.
[15] T. Kokusho, "Water film in liquefied sand and its effect on lateral spread," ASCE Journal of Geotechnical and Geoenvironmental Engineering, vol. 125, no. 10, pp. 817-826, 1999.

[16] T. Kokusho and T. Kojima, "Mechanism for post-liquefaction water film generation in layered sand," ASCE Journal of Geotechnical and Geoenvironmental Engineering, vol. 128, no. 2, pp. 129-137, 2002. 

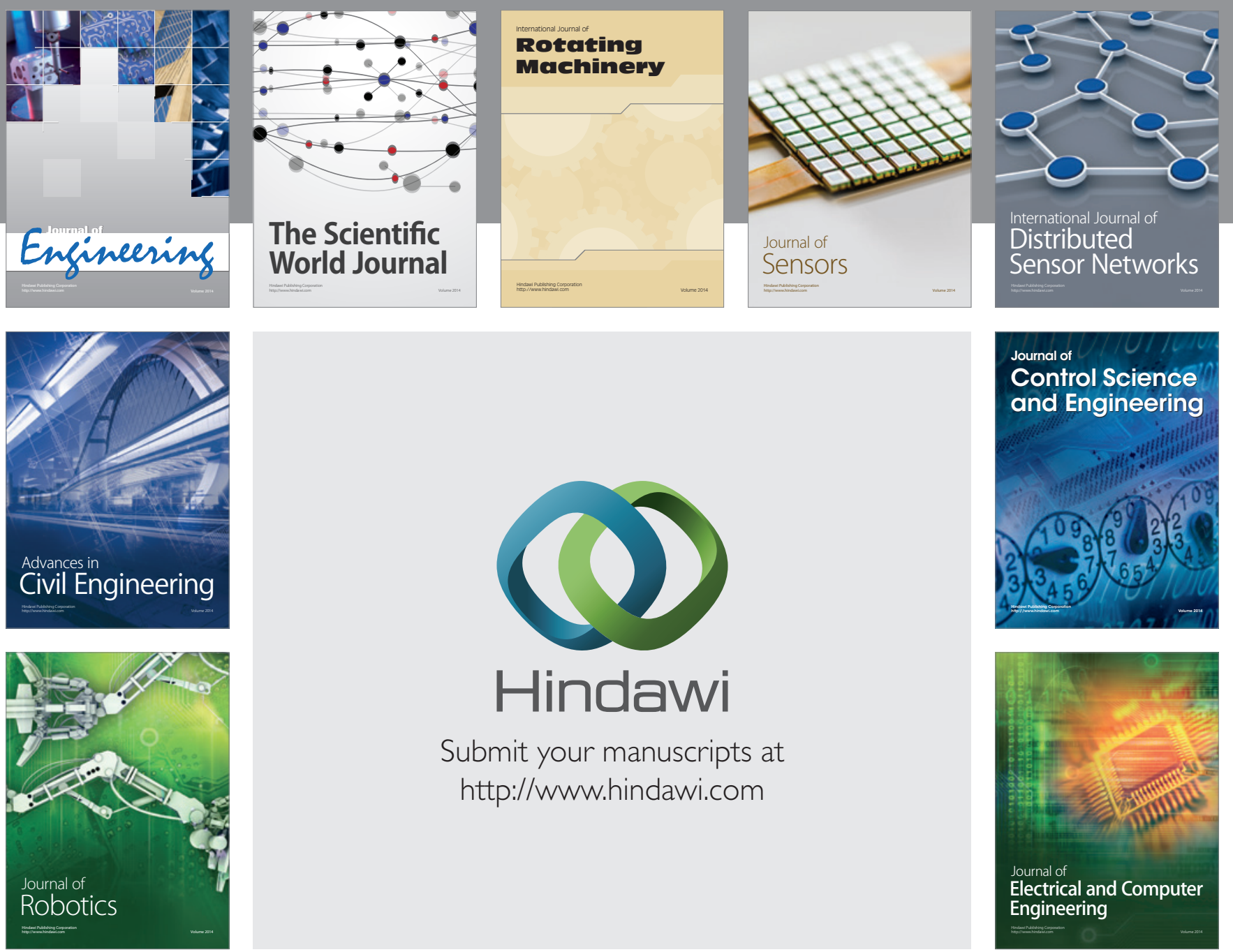

Submit your manuscripts at

http://www.hindawi.com
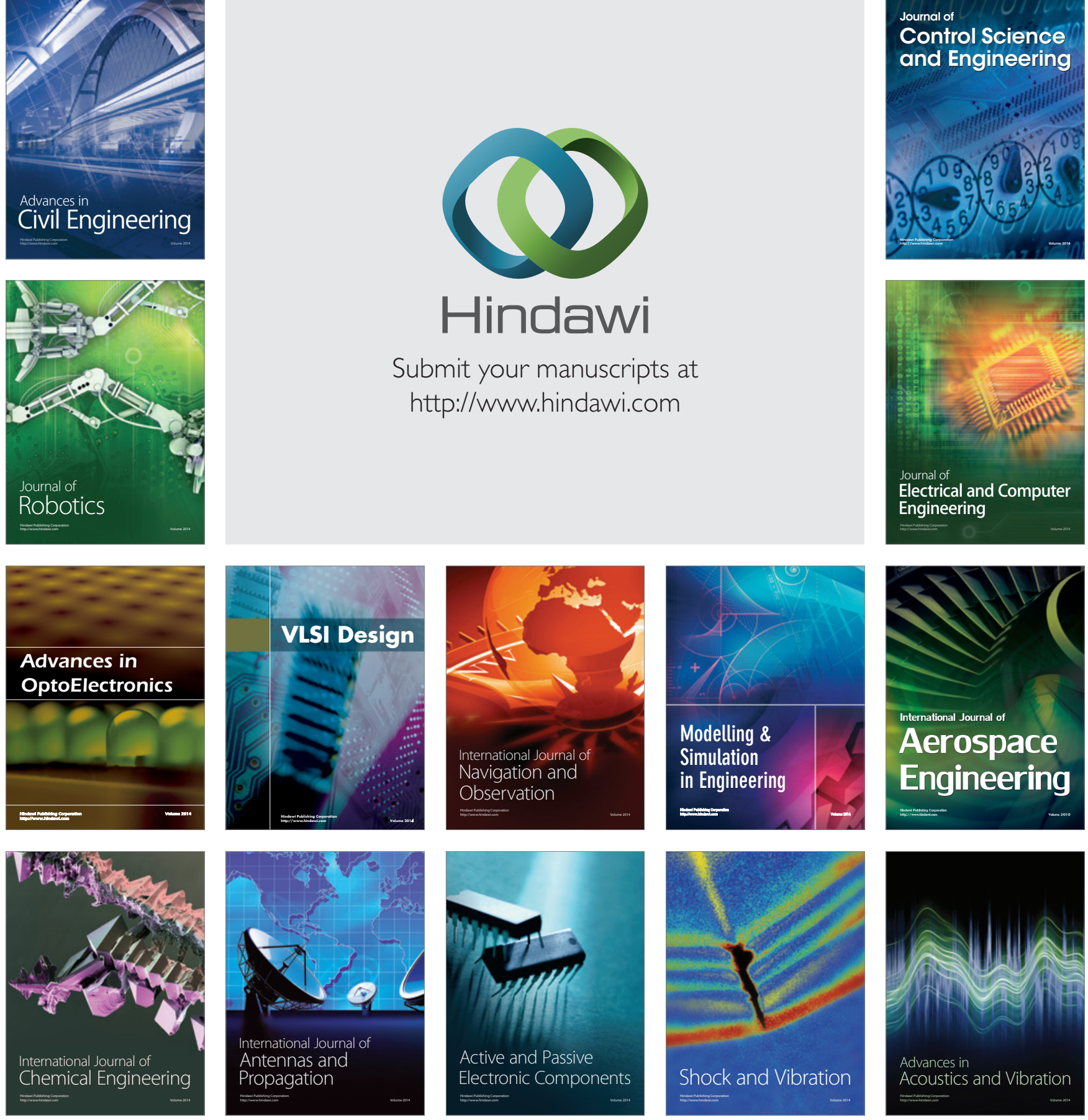